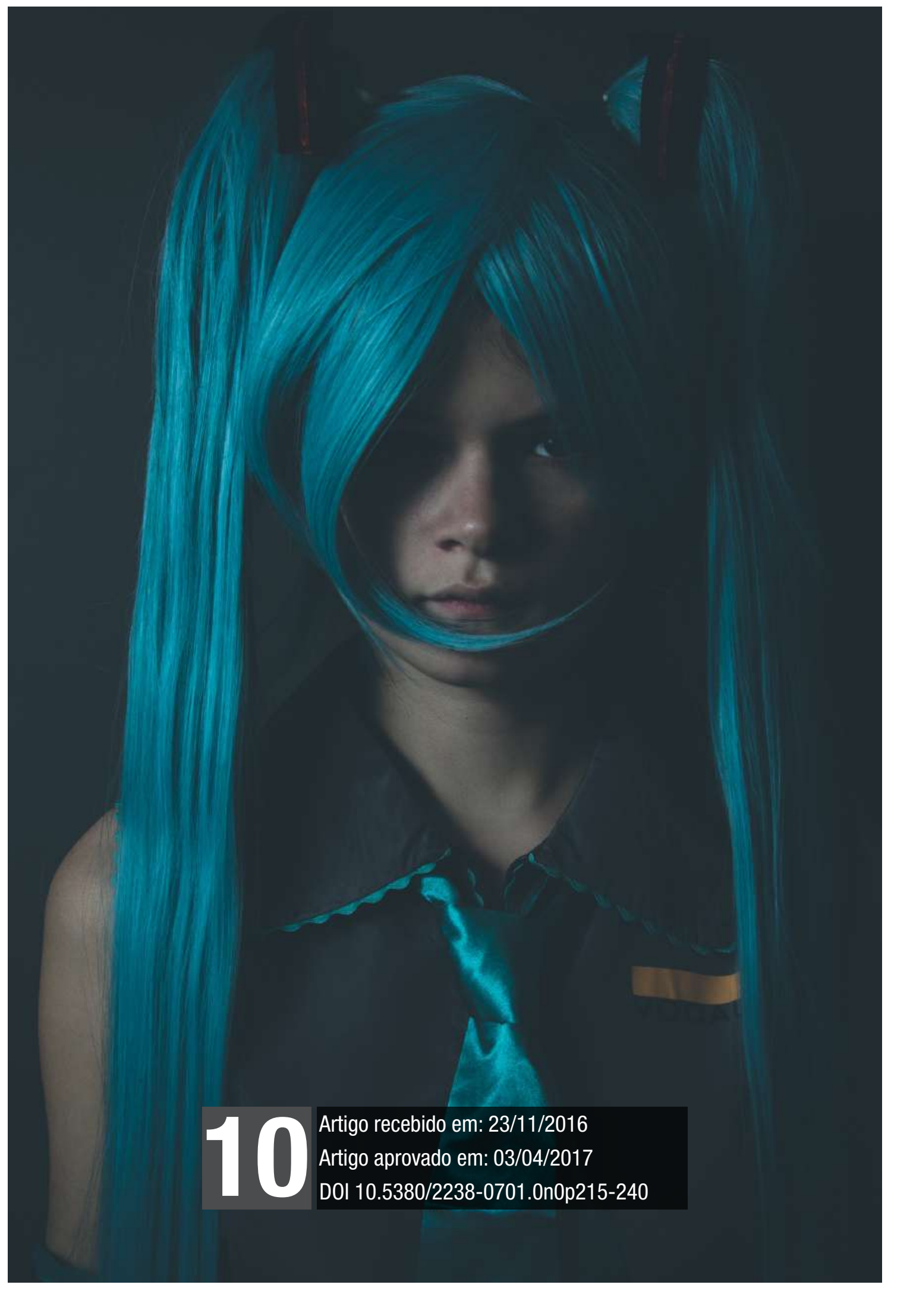


Mídia. Cultura. Animê. Jovens. 


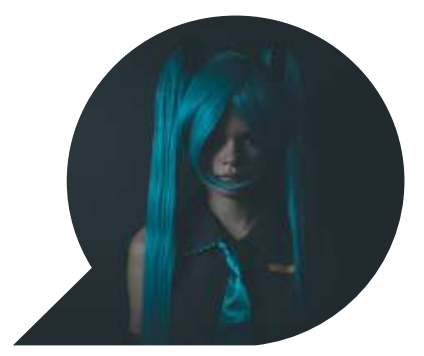

\title{
Animencontros: a relação da cultura midiática pop japonesa com grupos de jovens brasileiros
}

\author{
Animencontros: the relationship of Japanese pop media \\ culture with groups of young Brazilians
}

Animencontros: la relación de la cultura pop japonesa medios de comunicación con los grupos de jóvenes brasileños

\author{
CARLOS ALBERTO MACHADO ${ }^{1}$
}

ROSÁLIA MARIA DUARTE²

Resumo: Este artigo descreve e analisa a dinâmica de apropriação de elementos da cultura midiática japonesa por um movimento cultural organizado por jovens brasileiros, a partir de dados produzidos em uma pesquisa de campo. O objetivo desta foi analisar as práticas de jovens que se autodenominam "otakus" e que costumam se reunir em "animencontros", eventos organizados por jovens aficcionados por mangás e animês -, frequentados por milhares de crianças e jovens de todo o Brasil, que praticam atividades específicas e constroem, coletivamente, uma forma própria

\footnotetext{
${ }^{1}$ Doutor em Educação pela Pontifícia Universidade Católica do Rio de Janeiro (2009). Atualmente é professor adjunto da Universidade Estadual do Centro-Oeste (Unicentro), onde coordena o Grupo de Estudos e Pesquisas Tecnologia, Educação e Cultura - GETEC.

${ }^{2}$ Doutora em Educação pela Pontifícia Universidade Católica do Rio de Janeiro (2000). Atualmente é professora associada da PUC-Rio, onde coordena o Grupo de Pesquisa "Educação e Mídia", vinculado ao PPGE.
} 
de aproximação com essa produção cultural. $\mathrm{O}$ trabalho de observação e registro desses eventos foi realizado ao longo de 2006 e 2008 em quatro regiões brasileiras, nos moldes definidos para uma pesquisa qualitativa. Além das observações de campo, foram realizadas entrevistas estruturadas com 45 jovens frequentadores desses eventos. Observou-se, entre outras coisas, o processo de socialização que se configura entre jovens e os modos de aquisição compartilhada de conhecimentos específicos relativos à cultura pop japonesa, assim como os modos de organização interna dos eventos e seus rituais. Foram tomados como referência teóricometodológica trabalhos de autores ligados aos Estudos Culturais Latino-americanos e à cultura japonesa no Brasil, como Nestor García Canclini (2006), Jesús Martin-Barbero (1997) e Sonia Bibe Luyten (2005).

Palavras-chave: Mídia; Cultura; Evento de anime; Jovens.

Abstract: This article describes and analyzes the dynamics of appropriation of elements of Japanese media culture by a cultural movement organized by young Brazilians. The objective of the research was to analyze the practices of young people who call themselves "otakus" and who usually meet in "animencontros", events organized by young people who are fond of manga and anime - frequented by thousands of children and young people from all over Brazil, where they practice specific activities and Construct, collectively, a proper form of approximation with this cultural production. The work of observation and registration of these events was carried out throughout 2006 and 2008, in four Brazilian regions, in the manner defined for a qualitative research. In addition to field observations, structured interviews were conducted with 45 young people attending these events. Among other things, the process of socialization between the young and the modes of shared acquisition of specific knowledge of Japanese pop culture, as well as the modes of internal organization of events and their rituals, were observed. Works by authors related to Latin American Cultural Studies and Japanese culture in Brazil such as Nestor García Canclini (2006), Jesús Martin-Barbero (1997) and Sonia Bibe Luyten (2005) were taken as theoretical-methodological references.

Keywords: Media; Culture; Anime event; Young. 
Resumen: En este artículo se describe y analiza la dinámica de apropiación de los elementos de los medios de comunicación la cultura japonesa por un movimiento cultural organizado por los jóvenes brasileños. El objetivo de la investigación fue analizar las prácticas de los jóvenes que se hacen llamar "otakus" y, a menudo se reúnen en "animencontros", eventos organizados por jóvenes entusiastas por el manga y el anime - frecuentada por miles de niños y jóvenes de todo el Brasil, donde se practican actividades específicas y construir, colectivamente, a su manera de acercarse a esta producción cultural. El trabajo de observación y registro de estos eventos se llevó a cabo en 2006 y 2008 en cuatro regiones de Brasil, en la forma prevista para una investigación cualitativa. Además de las observaciones de campo, se realizaron entrevistas estructuradas con 45 jóvenes asistentes a estos eventos. Hubo, entre otras cosas, el proceso de socialización que se configura entre los jóvenes y los modos de adquisición compartida de conocimientos específicos de la cultura pop japonesa, así como los modos internos de organización de eventos y rituales. Ellos se tomaron como obras de referencia teóricos y metodológicos de autores vinculados a los estudios culturales en América Latina y la cultura japonesa en Brasil y Néstor García Canclini (2006), Jesús Martín-Barbero (1997) y Sonia Bibe Luyten (2005).

Palabras clave: Medios; La cultura; El anime de eventos; Jóvenes. 


\section{Introdução}

A pesquisa de que trata este artigo teve como foco principal a busca de um entendimento mais aprofundado sobre a relação entre um número expressivo de jovens brasileiros e os mangás ${ }^{3}$ e animês ${ }^{4}$, exibidos pelas emissoras de televisão em todo o mundo e, de forma muito particular, pelo que é denominado, no Brasil, como "animencontros", ou encontros de animês. Esses eventos são frequentados por jovens que se autodenominam “"otaku”" brasileiros.

Segundo Barral (2000), o ““'otaku”” propriamente dito, surgiu no Japão, no início dos anos 1980, devido ao poder cada vez maior dos meios de comunicação de massa, à prática do consumo de produtos tidos como culturais, ainda que fabricados em série, e à dificuldade dos adolescentes em assumir responsabilidades de adultos.

Conforme Nagado (2005) o jornalista japonês Akio Nakamori, após observar esse fenômeno que atualmente vem assolando o Japão, foi o responsável pela difusão do termo, pois, de acordo com Luyten (2000) e Poitras (2005) antes da década de 1980, o significado de o-taku não era pejorativo como é hoje no Japão e significava "a vossa casa" em japonês.

Já no Brasil, a palavra “"otaku”' é a forma mais comum de denominação de fãs de cultura pop japonesa, já que essa palavra adquiriu outro sentido no ocidente. Ainda, segundo Nagado (2005) e Sato (2007), em razão de sua difusão em revistas especializadas, o termo se espalhou rapidamente entre os fãs como sinônimo de colecionador de mangás e "animês". Hoje, é comum os meios de comunicação utilizarem a palavra "otaku".

Por uma questão cultural brasileira, há pouco espaço aqui para o "otaku" clássico. O público brasileiro é formado por muitas garotas e casais de namorados "otaku"s, o que seria uma contradição no Japão. Muito mais soltos, entusiastas e barulhentos do que suas contrapartes orientais, os fãs brasileiros se acotovelam por um autógrafo de seu dublador preferido, pulam ouvindo anime songs ${ }^{5}$ como se estivessem em um show de rock e promovem uma confraternização bem brasileira, que certamente, estão distantes do fanatismo solitário e isolado presente em muitos "otaku"s japoneses. (NAGADO, 2005: 56)

\footnotetext{
${ }^{3}$ Revistas em quadrinhos japoneses com temáticas para crianças, jovens e adultos. Mangá na linguagem japonesa significa "histórias em quadrinhos". É o resultado da união de ideogramas man (humor, algo que não é sério) e gá (imagem, desenho) (MOLINÉ, 2004).

${ }^{4}$ Desenho animado japonês. No Japão anime é designado para todo tipo de desenho animado.

${ }^{5}$ Músicas de "animês".
} 
Assim, é possível afirmar que esse processo de sociabilidade, objetivo principal desse artigo, ancora-se, a princípio, na relação estabelecida por esse grupo de jovens com mangás e animês, o que contribui para a configuração de um determinado insight, um novo estilo de vida, uma forma de cultura construída e vivenciada por eles, a qual ajuda a configurar um modo próprio de estar no mundo. Esta cultura, celebrada especialmente nos "animencontros", expressa-se em um modo particular de se vestir, de falar, de dançar, comer e assim por diante.

$\mathrm{Na}$ vida cotidiana, os jovens tendem a identificar-se com seus iguais e a diferenciarem-se dos outros, especialmente do mundo adulto. Criam rituais e "instauram procedimentos de resistência e criatividade, conferindo certo grau de imprevisibilidade aos mecanismos de orientação social." (CARRANO, 2003, p. 22). Também costumam utilizar a mídia - um destes mecanismos - como forma de se contrapor a ela, aos seus discursos e orientações.

Como nos recorda o mesmo autor, as "viagens virtuais" e a sociabilidade dos encontros eletrônicos na Internet, são possibilidades culturais e associativas que ampliam e modificam o mundo de muitos jovens. Esta sociabilidade vem atravessada de novas culturas, podendo se configurar no que é denominado de mundialização.

A mundialização está se consolidando por questões de interesse nacional e internacional, que ultrapassaram fronteiras. As fronteiras tradicionais se transformaram, configurando-se de forma mais porosa e mais cambiante, o que facilitou novas práticas de agrupamentos e de relações entre comunidades.

\section{Mangás e animês no contexto atual}

Os mangás e os animês são exemplos de mundialização cultural muito evidentes entre nós. Ambos são produtos culturais midiáticos de origem japonesa, criados para o entretenimento local, que acabaram intencionalmente ou não, atuando como veículos importantes na difusão de valores e pressupostos da cultura daquele país. Os mangás e animês podem ser considerados elementos "estranhos" à cultura de origem dos jovens brasileiros. No entanto, são reinterpretados por um determinado grupo que não os vê com estranhamento, pois está aberto a novas culturas, valores e costumes e os traduz, a seu modo e no seu tempo, em uma cultura diferenciada.

De modo despretensioso os animês surgiram no Brasil, nas décadas 
de 1960 e 1970 do século passado, mas foi apenas na década de 1990, com a vinda da série "Cavaleiros do Zodíaco" na extinta Rede Manchete, e do anime "Dragon Ball" por canais de TV por assinatura, que o interesse dos jovens brasileiros por esse tipo de produção foi despertado. Com o advento da internet e da TV por assinatura ${ }^{6}$, muitas outras seguiram, aumentando e reforçando ainda mais o interesse pelo assunto.

Em razão desse interesse por parte dos jovens brasileiros pela cultura japonesa, editoras brasileiras interessaram-se em lançar mangás traduzidos para nosso idioma. A princípio, na década de 1980 foram editados nos padrões culturais ocidentais, mas nas duas últimas décadas seguem o padrão de origem, ou seja, com a leitura realizada da direita para a esquerda. Atualmente é comum encontrarmos mangás em bancas de jornais e livrarias brasileiras, o que faz com que estes atinjam um grande número de leitores, sobretudo jovens. A procura por mangás no Brasil já ultrapassa a venda de outros quadrinhos, mesmo os estadunidenses mais conhecidos editados por Marvel Comics e DC Comics.

Os leitores desses mangás, que em geral também são assíduos espectadores dos animês, sentindo a necessidade de trocar informações sobre a temática oriental, passaram a realizar eventos com este fim, aos quais denominam-se "animencontros". Porém, os mangás e os animês não foram os únicos responsáveis por esses encontros. Pode-se considerar Sonia Luyten - uma das primeiras pesquisadoras a se inteirar no assunto - como precursora desse tipo de evento fazendo parte do grupo de fundadores da ABRADEMI (Associação Brasileira de Desenhistas de Mangá e Ilustrações) de São Paulo. Em 1984, Luyten ajudou a organizar encontros relacionados ao mangá, como os Mangacom (que tiveram pelo menos quatro edições consecutivas). Estes eventos se disseminaram, a partir de então, em reuniões públicas realizadas por jovens em espaços escolares nos finais de semana, inicialmente nas capitais de São Paulo e Curitiba, sendo, gradativamente ampliados e espalhando-se por diferentes regiões do país, tornaram-se independentes uns dos outros. Ocorrem em fins de semana e sua duração costuma prolongar-se em média por dois dias. São realizados, geralmente, em escolas, colégios, faculdades ou universidades e algumas vezes em clubes ou salões de festas em conjuntos habitacionais.

\footnotetext{
6 "Assistir a televisão é a atividade realizada por 91\% dos jovens." (BRENNER, DAYRELL e CARRANO, 2008:35)
} 


\section{A cultura dos "animencontros"}

Os "animencontros" são organizados por jovens na faixa etária dos 18 a 23 anos. A idade dos participantes varia entre 16 e 34 anos $^{7}$. O espaço sempre é aproveitado ao máximo, sendo os mais destacados para utilização dos patrocinadores, que normalmente são comerciantes da própria cidade especializados em objetos relativos aos mangás e animês. As principais atrações são: cursos de desenho (estilo mangá); origami (dobraduras em papel); jogos do tipo Go (jogo de tabuleiro); pintura em bonecos de chumbo; arco e flecha; cards (jogos de cartas); RPG's (jogos com dados e tabuleiros); concursos de videogames; exibição de filmes tokusatsu'; Super Sentai ou live-action e "animês"; palestras com desenhistas de mangás, dubladores ou tradutores dos animês; animekês (cantam músicas decoradas dos animês em japonês); animequiz ${ }^{9}$ (respondem a conhecimentos gerais sobre o conteúdo dos mangás e animês); shows de j-rock (em sua maioria músicas japonesas de animês), para-para (dança moderna japonesa) ou apresentações especiais, como artes marciais, "dança bom odori” (dança tradicional japonesa), adaptada para o animê e, principalmente, apresentações teatrais e desfile de cosplay $^{10}$ - as mais aguardadas.

A cultura dos "animencontros" parece resultar de um processo mais ou menos aleatório de apropriação - utilizado aqui no sentido de tornar próprio, incorporar - de elementos originalmente estranhos uns aos outros, criando configurações que poderiam ser definidas como híbridas.

Processos de hibridação acontecem em condições históricas e sociais específicas, em meio às normas de produção e de consumo. Segundo Canclini (2006a), tratam-se de "processos socioculturais nos quais estruturas ou práticas discretas que existiam de forma separada, se combinam para gerar novas estruturas, objetos e práticas." (CAN-

\footnotetext{
${ }^{7}$ Para essa pesquisa foram consideradas a faixa etária entre 16 a 34 anos como referente à juventude, bem acima do tradicionalmente utilizado em estudos demográficos como lembra Dayrell (2005) que se limita aos 24 anos. Portanto, apesar da presença de outras faixas etárias no grupo cultural pesquisado meu recorte de análise será a juventude. Um alongamento de faixa etária, um tipo de nova fase denominada pós-adolescência. (SPOSITO, 1997: 39)

${ }^{8} 0$ termo vem de "tokushu kouka satsuei" que é traduzido como "filme de efeitos especiais" Ex. Changerman, Nacional Kid, UltraMan, UltraSeven, Jiraya, Power Rangers etc.

${ }_{9}^{9}$ A palavra animequiz foi encontrada escrita de várias maneiras. Para esse trabalho será utilizada animequiz com exceção para as publicações citadas.

${ }^{10}$ Alguns otakus vestem-se de acordo com uma personagem de animê e costumam representá-lo no palco diante de seus colegas em desfiles ou concursos para esse fim. Cós=fantasias e play=brincar, ou seja, brincar de fantasias.
} 
CLINI, p. XIX). A hibridação, como procedimento de interseção e acordos, é o que possibilita que a multiculturalidade evite a segregação e se transforme em interculturalidade (CANCLINI, idem). Isso explicaria o forte interesse por uma cultura "estranha", separando-se ou ignorando certos aspectos particulares e adaptando-os à sua própria cultura. No caso dos “"otaku”"s" brasileiros, o significativo interesse pela cultura nipônica não carrega consigo aspectos culturais contraproducentes, que poderiam alterar de forma imprevisível nossa própria cultura, pois a hibridação transforma o multiculturalismo em interculturalidade (CANDAU, 2012).

Este tema, um tanto polêmico - o surgimento de uma nova cultura juvenil, híbrida do encontro entre as culturas de origem de jovens ocidentais e elementos da cultura japonesa, presentes nos mangás e animês - foi escolhido em função do interesse pela atitude peculiar destes jovens e também pelo entendimento que se trata de processos de socialização e sociabilidade, cuja extensão e amplitude ainda não foram suficientemente avaliados.

Entende-se por cultura (ORTIZ, 1994), um sistema de signos e símbolos que articulam significados. Estes significados são resultantes das articulações produzidas em contextos regionais específicos, com seus elementos e características próprias. O reconhecimento de que pode haver diferentes formas, próprias e singulares de articular significados dentro de um mesmo espaço geográfico, ou no interior de uma mesma sociedade ou nação, leva os estudiosos contemporâneos a falar em culturas no plural, contestando a ideia clássica de existência de uma única cultura nacional ou regional, que aglutinaria diferentes grupos sociais.

\section{Recorrências - o funcionamento dos “animencontros" - ritualidades}

Demonstrar algum domínio dos elementos da cultura japonesa e dos produtos culturais que os veiculam constitui-se no universo dos "otaku", de um tipo de ritual de passagem, pois este conhecimento se faz necessário para ser admitido como integrante deste grupo e sentir-se pertencente a ele. Canclini (2006a) recorda que todas as culturas utilizam rituais, pois sua capacidade de apanhar o sentido afetivo das modificações sociais, "a polarização, discrepância e condensação entre sentidos, a ritualidade, que, segundo Turner”, citado por Canclini (2006a:364), "é mais propícia que outras práticas: serve para viver - e para observar - os processos de conflito e transição. O 
pensamento simbólico e ritual tem uma ' função nodal com respeito a séries de classificações que se entrecruzam.”

A mediação comunidade das ritualidades trata da conexão simbólica que sustenta toda comunicação, isto é, o seu apego à lembrança, com seus ritmos e formas, seus panoramas de interação e repetição. Localizada em meio às lógicas de produção, os formatos industriais e a recepção ou o consumo, as ritualidades instituem-se como "gramáticas de ação - do olhar, do escutar, do ler - que regulam a interação entre os espaços e tempos da vida cotidiana e os espaços e tempos que conformam os meios." (MARTIN-BARBERO, 2003, p. 19). As ritualidades ressaltadas pela recepção e pelo consumo, enviam, por um lado, aos distintos usos sociais dos meios e, por outro, às múltiplas direções de leituras interligadas às condições sociais da vontade, limitadas por níveis e qualidade de educação, por conhecimentos e saberes constituídos na memória étnica, de classe ou gênero, e ainda, por costumes familiares de coexistência com a cultura letrada, oral ou audiovisual, que carregam a experiência do ver sobre ler e vice-versa.

$\mathrm{Na}$ investigação foi possível observar com relação às plaquetas, que esta troca de informação pode ser vista como uma ritualidade que ocorre no interior dos "animencontros", também possível de serem nomeados como rituais. A simbologia encontrada nas plaquetas, a repetição de atividades rituais se transformam em um reencantamento do mundo, por meio da constante visualização de mangás e de animês, criando hábitos de leitura e um olhar único e diferenciado.

O papel desempenhado por essa ritualidade, no sentido atribuído por Barbero (2003) ao termo, atua na mediação entre a competência da recepção - o modo como o receptor lida com os produtos da indústria cultural (sentido dado por Adorno), estabelece seus diálogos com esta produção e interfere na criação de novos produtos (sempre culturais). Isso foi notado, por exemplo, na observação dos cosmakers e do cosplay original $^{11}$. Ambos se preocupam com a criatividade e a confecção de novas roupas, novos visuais, embora, obviamente, estes receptores também sejam afetados pela indústria cultural. $\mathrm{O}$ cosplay original, apesar deste nome, possui alguns elementos que fazem parte da cultura pop tradicional japonesa.

Os "animencontros", dessa maneira, se tornam mediadores socioculturais responsáveis pelo surgimento de movimentos sociais que acabam introduzindo novos sentidos do social e novos usos sociais dos

${ }^{11}$ Explicação dos termos mais adiante em "categorias de cosplay". 
meios. A maneira como o "otaku", neste caso, o receptor, lida com esses produtos da indústria cultural, estabelece diálogos com essa produção e interfere na criação de novos produtos. O esquema a seguir (figura 1) é proposto por Martin-Barbero (2003), que traça o mapa das relações entre comunicação, cultura e política.

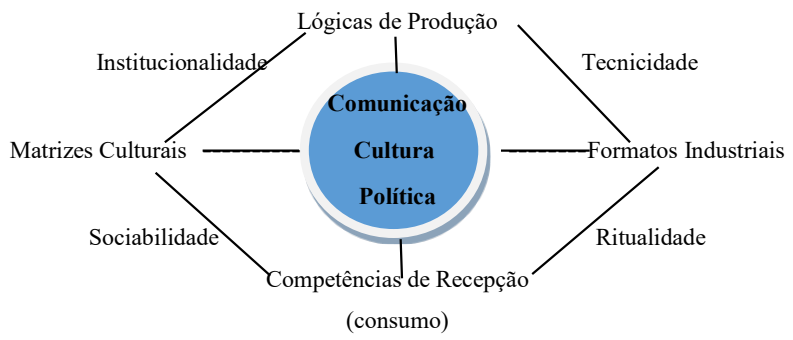

Figura 1 - Esquema de Martin-Barbero, Jésus. Dos meios às mediações: comunicação, cultura e hegemonia. RJ: Editora da UFRJ, 2003:16.

No esquema de Martin Barbero (2003) é possível idealizar uma representação dos "animencontros". Podemos observar permanências e transformações das diversas práticas presentes nas diferentes regiões brasileiras observadas, que foram organizadas em práticas rituais, práticas sociais, de novidades tecnológicas, de lógicas de produção, e de formas de organização, que se modificaram conforme a localidade. Nota-se que muitos desses procedimentos (danças, estilos de desenho e moda, jogos etc), continuam presentes, muitas vezes perdendo seu sentido original e adquirindo novos significados. Mesmo apreendendo a segmentação de muitos formatos, foram reelaborados e adquiriram nova expressão entre seus participantes. A pesquisa da qual se origina o presente artigo deteve-se justamente nos métodos cerimoniais e nas práticas sociais relativas à complexidade dos "animencontros" práticas estas estabelecidas no choque e no intercruzamento entre diferentes culturas presentes naquela temporalidade e naqueles espaços geográficos.

Ao apreender, de acordo com Martin-Barbero (2003), que a comunicação deve ser problematizada na ação criativa do universo onde a produção e o consumo recebem sentido, a leitura do massivo ganha um outro aspecto na trajetória desta pesquisa ao deixar de ser vista como mecanismo isolável e, sem sombra de dúvidas, torna-se uma nova forma de sociabilidade. Portanto, pensar os "animencontros" a partir do 
massivo e das considerações do referido autor, não significa discorrer a respeito da alienação e da manipulação e, sim, de novas categorias de vivência, um original modo de existência de grupos juvenis brasileiros.

Assim sendo, os "animencontros" trazidos ao contexto comunicacional, a que se refere Martín-Barbero, tornam-se mediadores socioculturais, constituindo novos sentidos do social e novos usos sociais dos meios, como pode-se observar na explicação que o autor (2003) faz do esquema:

[...] os movimentos étnicos ou de gênero, introduzem novos sentidos do social e novos usos sociais dos meios. Sentidos e usos que, em seus tateios e tensões, remetem por um lado à dificuldade de superar a concepção e as práticas puramente instrumentais para assumir o desafio político, técnico e expressivo, que supõe o reconhecimento na prática da complexidade cultural que hoje contêm os processos e os meios de comunicação. Porém, por outro lado remetem também à lenta formação de novas esferas do público e às novas formas de imaginação e de criatividade social. (MARTIN-BARBERO, 2003, p. 20-21).

Sendo os "animencontros" um processo de ritualidades, também está contido de outras ritualidades como veremos mais adiante.

Mas por que um grupo de jovens brasileiros aprecia tanto os mangás e animês japoneses? Possivelmente a resposta a essa pergunta esteja na simples comparação com as histórias em quadrinhos e os desenhos animados ocidentais, que são mais focados na fantasia, em detrimento da verossimilhança com a vida real. De um modo geral, os jovens apreciam essa aproximação com o real.

Outro fator que poderia explicar esse interesse pelos mangás e animês, pois esse último costuma seguir a tendência do primeiro, também pode estar localizado na psicologia das personagens e na técnica dos mangakás japoneses (artista de mangá). A psicologia dos personagens japoneses é bastante bem elaborada. Como lembram (MOLINÉ, 2006; SMIRKOFF, 1996; VASCONCELLOS, 2006, e GRAVETT, 2006), as personagens nipônicas possuem defeitos e sentimentos (como alguns personagens de HQs estadunidenses): riem, choram, crescem, amadurecem e alguns morrem. As personagens aprendem a partir de seus erros em paralelo ao desenvolvimento do mangá ou da produção do animê. "São numerosos mangás que trazem uma 'viagem de iniciação', em que o protagonista - que, na maioria das vezes é jovem - se transforma de menino em adulto e descobre o próprio sentido da existência e sua missão de 
vida." (MOLINÉ, 2006, p. 30). As personagens vão amadurecendo, física e psicologicamente passando por um processo gradativo tendo sentimentos e valores desenvolvidos como amizades e responsabilidades.

Outra observação significante com relação aos animês indicados pelos próprios jovens "otaku"s pesquisados, demonstra que as mensagens contidas nos roteiros estão imbuídas de valores, que são muito apreciadas por eles:

Karine 16 anos (DF): Nossa, eu aprendi muita coisa. Eu acho que expandiu minha cabeça pra cultura e é aquela velha coisa, [...] a maioria deles né?, dos "animês", todos eles, tem alguma lição de moral pra passar. Não vai ter nenhum que vai ser totalmente supérfluo, todos vão ter alguma coisa pra te passar. Sempre tem uma mensagem principal.

Para a realização deste estudo, optou-se por uma pesquisa qualitativa, com registros fotográficos e videográficos, cujos procedimentos incluíram, além de observações de campo registradas por escrito, entrevistas com "otakus" (entre participantes e cosplayers) semiestruturadas (audiogravadas) e fotografias analógicas e digitais.

As observações iniciaram-se no Rio de Janeiro no dia 23 de março de 2006 e foram realizadas até o dia 23 de setembro de 2007, quando da participação do último evento na cidade de Curitiba, no estado do Paraná. Durante o ano de 2008, ainda ocorreu a participação de mais alguns eventos na mesma cidade para complementar o registro fotográfico para esta pesquisa.

Desta forma, a pesquisa de campo abrangeu eventos na cidade do Rio de Janeiro (RJ), São Paulo (SP), Ribeirão das Neves (MG), Brasília (DF), Fortaleza (CE), Curitiba (PR), Blumenau (SC) e Porto Alegre (RS), finalizada em junho de 2008, nas cidades de São Paulo e Curitiba. Ao total, foram visitados 25 "animencontros" ou eventos de animê, os quais proporcionaram uma melhor compreensão deste novo universo analisado.

\section{Os frequentadores de "animencontros" brasileiros}

Como são aficionados por mangás e "animês", as conversas entre os participantes dos eventos giram, quase sempre, em torno do assunto: trocam opiniões sobre as séries de televisão e os novos lançamentos, fazem críticas, sugerem, aconselham etc. Muitos consideram o "otakismo" um estilo de vida e alguns costumam trajar-se, cotidia- 
namente, como tal (estilo "kei"). Isso facilita o encontro dos "iguais", pois elementos visuais e vestimentas ajudam na identificação daqueles que pertencem ao grupo.
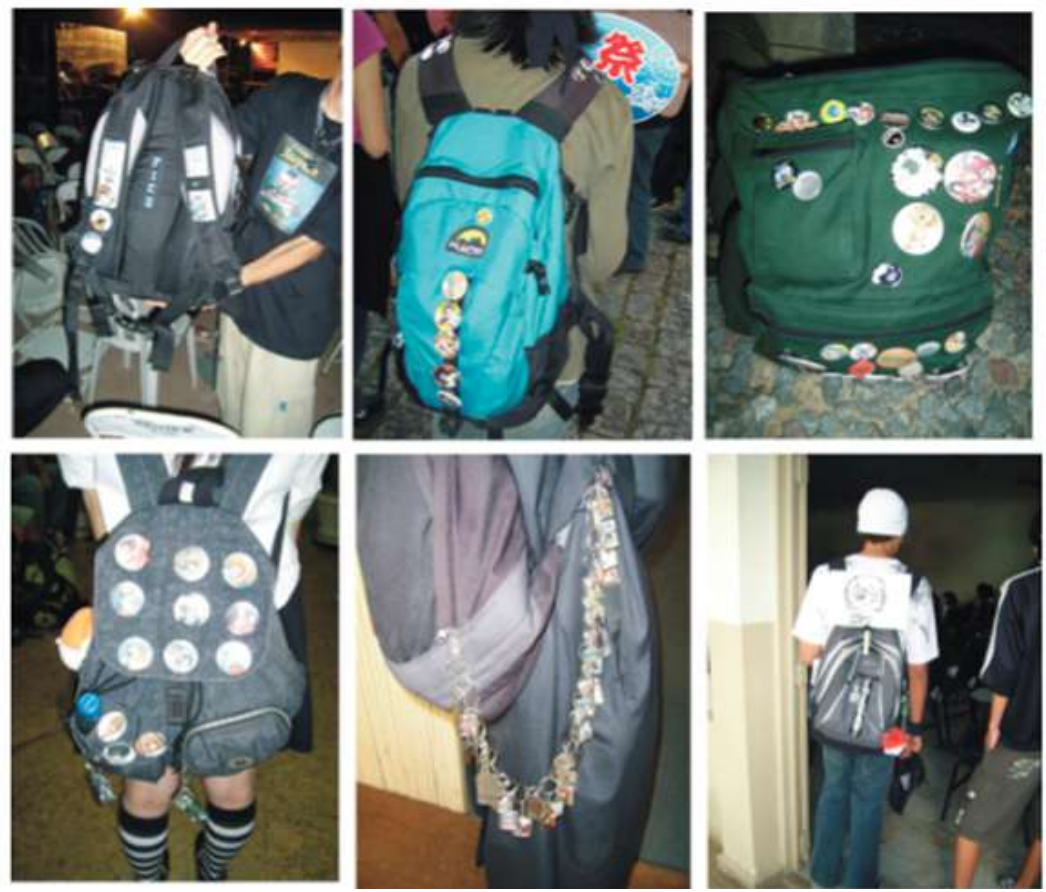

Figura 2 - Mochilas de "otaku"s brasileiros repleta de botões ou chaveiros com ícones dos "animês"

Alguns participantes admitem trajar-se como tal apenas nos "animencontros", tendo comportamento diferenciado em outros locais, como indicam as falas de alguns deles, em entrevista concedida ao pesquisador:

[...] às vezes a gente acaba conhecendo alguém com uma camiseta, por um bóton, por um chaveirinho na mochila (Diego, 21 anos, SC).

[...] geralmente todo "otaku" ele carrega sua mochila, vamos dizer assim 'é uma parte do seu corpo', então a gente sempre acaba enchendo de chaveiros ou bótons, vamos dizer 'é o que identifica um "otaku", de longe assim. (idem).

Eu só vou com minha camisa de animê quando...tem alguma coisa fora de horário, por exemplo, no sábado eu passo lá pra pegar alguma coisa, eu vou com camisa de animê. (Valéria, 31 anos, CE). 
[...] eu já me visto em casa e já vou pro evento vestido no meio da rua, vou eu e mais alguns amigos. (André, 18 anos, MG).

Eu só só não vou assim com [algo] na calça pra não dar muito problema lá na firma. Mas assim, se eu puder sair com alguma coisa de animê ou de mangá eu saio, numa boa, não tem nenhum problema não. Mas na mochila não, na mochila tem que ter alguma coisa penduradinha, ou alguma coisa ou muitas coisas penduradinhas. (Cláudia, 36 anos, RJ):

\section{A moda "otaku" e o estilo "kei"}
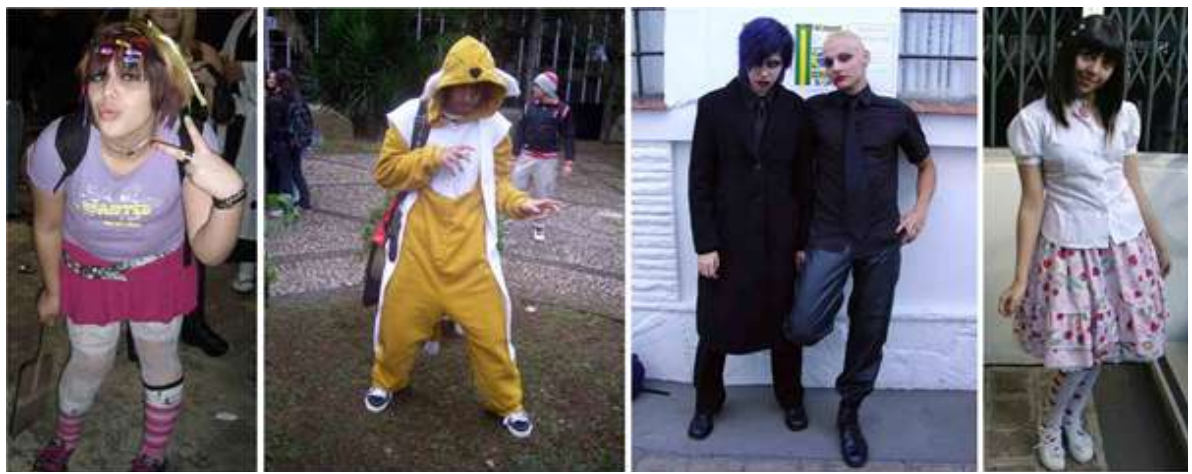

Figura 3 - Decora, Kugurumim, Casal de visual kei e Sweet Lolita

A influência do Japão é preponderante na vestimenta dos "otaku" brasileiros, os quais costumam frequentar os "animencontros" usando o que eles definem como estilo Kei, do quel fazem parte, entre outros : Decora (estilo colorido com desenhos de bichos em miniatura, chamados kawaii, que significa "adorável, fofo, bonitinho"12); Kugurumim ou Anime Goodies (inspirados nos bichos e personagens de animês), Visual $\mathrm{Kei}^{13}$ (baseado em grupos de $\mathrm{j}$-rock) ou na mistura deles, como preferem alguns (figura 3).

Há também o estilo Lolitas, que recorda bonecas vitorianas. Subdividem-se em Gothic Lolita, Sweet Lolita, Rock Lolita ou Dark Lolita. Esse grupo, em particular, em alguns eventos ou fora deles, costuma organizar pequenos chás ao estilo inglês, configurando mais um traço do hibridismo que caracteriza essa cultura.

\footnotetext{
${ }^{12}$ Não existe uma obrigação específica para esse estilo, mas costumam usar pantufas, cores tons pastéis e os acessórios normalmente incluem brinquedos e bolsas com personagens de desenhos infantis em geral que incluem desenhos ocidentais como "ursinho Puff", "ursinhos carinhosos", "meninas superpoderosas" e personagens Disney entre outros.

${ }^{13}$ Linhagem visual ou estilo visual que surgiu no Japão na década de 80.
} 
Toucas, orelhas e rabos, muito comuns em todos os eventos, também conhecidos por Anime Hads, Anime Goodies ou Kigurumi, segundo Keizi e Shamon ${ }^{14}$ (2007), são geralmente referências à personagens animais de "animês".

Ao que tudo indica, o estilo "otaku", além de pretender chamar a atenção dos não-iniciados nesta cultura, tem também uma função identitária, ou seja, atua como marca de pertencimento.

\section{Plaquetas como forma de comunicação}

Uma das práticas que chama a atenção imediatamente dos recém -ingressos no universo dos "animencontros" é a utilização de placas para comunicação entre os frequentadores, inspiradas em animês. Frases escritas em papel comum ou em cadernos universitários também são usadas como forma de comunicação interna. Quando não estão nas folhas dos cadernos, chamam a atenção por estarem escritas com canetas de ponta porosa em plaquetas brancas, de fórmica. Algumas dessas plaquetas lembram os intertítulos incorporados aos filmes mudos, cuja função era orientar o espectador para uma melhor compreensão do enredo.

A interpretação dos dizeres das plaquetas está sujeita à subjetividade individual, mas, como os "otaku" compartilham entre si as mesmas referências, essa comunicação parece acontecer com certa facilidade.
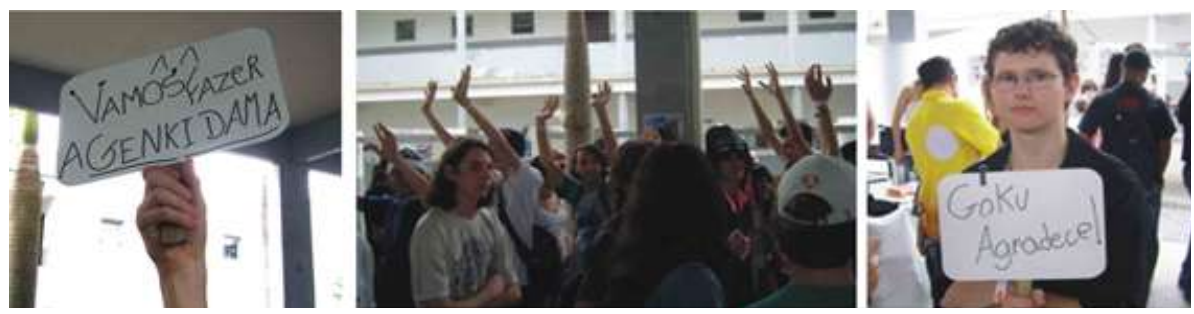

Figura 4 - "otaku" catarinense convidando colegas presentes a um animencontro a fazerem um "Genkidama”, baseado no animê Dragon Ball

O exemplo acima (figura 4) mostra um "otaku" catarinense usando a plaqueta para convidar os presentes em um evento a fazer um genki-

\footnotetext{
${ }^{14}$ Onmyoji Seto Shamon é o nome religioso do sacerdote da seita Zenchi Omnyodô conhecido como Cláudio Seto, artista plástico, escritor e desenhista de mangá brasileiro da década de 1980. Foi um dos principais responsáveis pela organização dos Matsuris de Curitiba. Chegou inclusive a ser homenageado com o Chibi Seto, o novo mascote dos Matsuris. Faleceu em novembro de 2008.
} 
dama, extraído da série de animê Dragon Ball. Na série, o protagonista Goku já sem forças, pede telepaticamente à população do planeta que levante seus braços para ceder solidariamente seus $k i^{15}$, e assim, ele possa fazer um genkidama (um tipo de bola de energia que seria a soma dos $\mathrm{ki}$ ), vencendo desta forma, um inimigo poderoso. O mesmo ato foi verificado durante a realização de um Matsuri 2008, na cidade de Curitiba.

\section{Danças orientais no Brasil}

Considerada uma importante forma de socialização, a dança também vem repercutindo fortemente entre os jovens "otakus" nos eventos em que estes se encontram e, como as demais atividades, são influenciadas principalmente na cultura tradicional japonesa.

O Matsuri Dance, também conhecido por Matsuri Odori, é um estilo diferenciado do Bon Odori ${ }^{16}$ e está se difundindo cada vez mais entre os jovens "otakus" brasileiros. É interessante observar como o Matsuri Dance, criado no Brasil, tem estreita relação com o Para Para criado no Japão e difundido pelo mundo. Segundo Macias e Evers (2007), as Takenokozoku (gangue broto de bambu), que dominaram a moda jovem do Japão nos idos de $1980^{17}$, revolucionaram a dança moderna japonesa quando, influenciadas pelo ritmo dos festivais religiosos ${ }^{18}$ do Bom Odori, criaram um estilo próprio, com movimentos próprios para cada música, mais rápido que a dança sincronizada, com todos fazendo o mesmo movimento, lembrando autômatos. Este estilo modernizou-se e atualmente é denominado

\footnotetext{
${ }^{15}$ Os "animês" e os mangás, trazem personagens com poderes provenientes de aprendizados sobre o fortalecimento do Qi ou chi na China ou ki no Japão. Além de Dragon Ball é possivel encontrar outros exemplos em The King of Fighter e Street Fighter. Outro exemplo bem conhecido é a série dos Cavaleiros do Zodíaco, onde os personagens principais procuram desenvolver sua capacidade de movimentar o Qi através de treinamentos físicos, meditações e do exercício da compaixão. De acordo com Freire (1996) o termo originalmente vem do chinês $Q i$ ou no japonês romazizado ki que se tradus ocidentalmente como um tipo de energia, também relacionado com a energia dos alimentos, do ar e a energia pré-natal. Um tipo de energia metafísica. Está intimamente relacionado com as artes marciais Tai-Chi-Chuan (chinesa) e Aikidô (japonesa).

${ }^{16}$ Dança tradicional japonesa, conhecida como dança de finados que se originou no período Kamakura (POITRAS, 2005).

${ }^{17} \mathrm{O}$ nome e o estilo são provenientes de uma boutique que abriu as portas em 1978 . 0 local vendia roupas largas, inspiradas na tradicional vestimenta japonesa, como os quimonos da era Heian (794 a 1185 d. C.). Mas os artigos eram caros. Por isso, as garotas de Chiba e Saitana tentavam a qualquer custo recriar o estilo da melhor forma possível. 0 resultado era um visual mais hip-hop do que clássico e chique. (MACIAS e EVERS, 2007: 28).

${ }^{18}$ Um desses festivais é "O Festival dos Mortos que vai de 13 a 15 de julho. [...] é uma forma de chamar os mortos para que visitem suas antigas moradas, passeiem pelas colinas cobertas de pinheiros, ao redor dos lagos e ao longo das praias, enfim pelos lugares que amavam. E isso durante os três dias que dura o Festival." (CASAS, 2004:12)
} 
Para Para, tendo sido adotado por milhares de jovens orientais e ocidentais, que dançam ao som de músicas agitadas, em especial o Eurobeat, usando principalmente o movimento dos braços.

\section{Jogo oriental de entretenimento}

Quando se observaram os participantes do evento em algumas situações fora das atividades regulares, seja na fila de espera, seja nos corredores ou pátios dos colégios onde ocorrem os eventos, formavam-se pequenos ou grandes círculos (entre 3 e 12 participantes) e começavam a realizar movimentos estranhos, como um tipo de pose.

Cada elemento que fazia parte do grupo realizava um gesto utilizando as mãos. Ora as colocavam na cabeça, hora em baixo do braço, em alguns momentos à frente. Posteriormente soube-se que tratava-se de um jogo chamado Huya. Ele possui origem relacionada ao horóscopo chinês. Esse jogo, bastante popular na China e de origem mandarim, era permitido nas escolas chinesas no regime pós-comunista. O jogo utiliza cinco figuras simbólicas do zodíaco chinês: Dragão ("??"19), Coelho (“\o/"), Serpente ou cobra (“|_O”), Águia (“o_o"), Tigre (“oOo") 20.
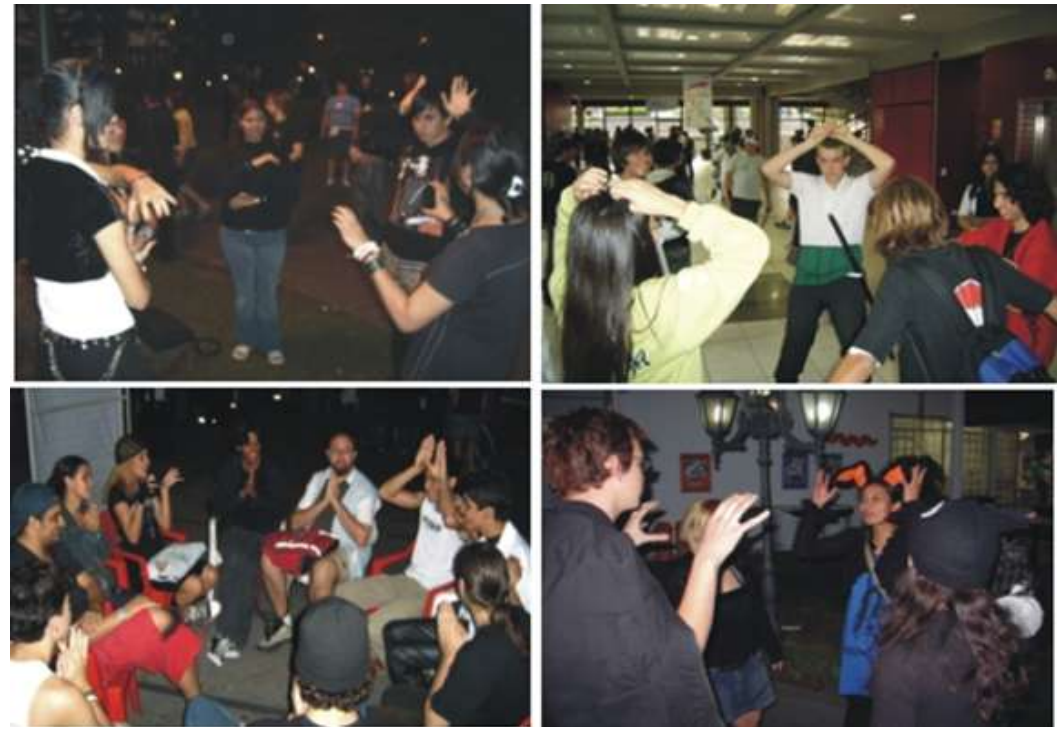

Figura 5 - “otaku”s curitibanos (acima) no Anime XD e no Matsuri 2007 (Praça do Japão) e cariocas (abaixo) no Circo Voador (RJ) jogando Huya

\footnotetext{
${ }^{19} \mathrm{O}$ símbolo do dragão é composto por duas interrogações.

${ }^{20}$ Como pode ser observado, os animais do horóscopo chinês estão intimamente relacionados com os do horóscopo japonês.
} 
Percebeu-se que, no interior de Minas Gerais, o Huya perdeu sua nomenclatura original, mas isso não impede que continue a ser praticado nos eventos mineiros. Esse tema foi abordado por alguns dos entrevistados dessa pesquisa:

Conheço, mas só em eventos. Igual tem o Rai [Huya]. É, tem gente que fala" Ia" e tem gente que fala "Rai", mas são cinco posições que toda vez que alguém fala "Ia", faz uma dessas posições e quem faz igual a quem gritou sai da brincadeira. (Alieche, 18 anos, MG).

[...] o de imitar bichos, ah sim, não, não jogo, mas quando eu tenho essa oportunidade nos eventos eu sempre curto jogar e tal só que fora dos eventos ai não dá. (André, 18 anos, MG)

Pesquisador: Você já viu o pessoal jogando esse jogo nos eventos?

Alguns sim, só não sei o nome porque eu não conheço [o nome], mas sempre quando tem eu participo. (André, 18 anos, MG)

Tem um que a gente joga aqui. A gente chama de Ya, aqui. Que a gente faz um movimento de alguns animais como o tigre, dragão, serpente, coelho, a gente faz esse e aqui. [fazendo gestos] Sempre nos eventos a gente junta uma galera, faz uma rodinha e faz essa brincadeira e é super -bacana que o povo todo se anima quando não tem nada pra fazer no evento a gente se anima pra caramba com essa brincadeira. (Antenor, 19 anos, MG).

\section{Categorias de cosplays}

Onde que lá fora você vai ter essa chance de se vestir como o seu personagem preferido? Não tem! O carnaval seria um outro evento que no momento você poderia se vestir, mas no carnaval você não consegue participar porque tematicamente falando você não pode representar. (Nilton, 31 anos, RJ)

Porque tem pai que diz "Ai, eu não vou deixar meus filhos se vestirem assim, eles são muito grandes pra isso." Quanto adulto não queria estar lá, sendo criança de novo? Deixa [a gente usar] a fantasia, deixa [a gente] ser criança. Acho que essa parte é importante, deixar a pessoa ser feliz do jeito que ela quiser ser, mesmo com fantasia ou sem. (Ariele, 18 anos, SC)

Em "animencontros" é normal evidenciar a presença de cosplayers. O visual varia desde personagens de animê e mangá, tokusatsus, até heróis de jogos eletrônicos e personagens de animações ou de filmes estadunidenses. 
Eles podem ser divididos em oito categorias: "cós-pobre”, "cós-pohia” ou "cós-feio" (categoria nativa, utilizada pelos "otaku", que varia de acordo com a região brasileira). São fantasias simples, sem preocupação com detalhes de acabamento e adereços sofisticados ou com gastos maiores; procuram usar roupas ou tecidos baratos.

"Toscoplay" (termo também cunhado pelos "otakus"): diferenciamse do "cosplay pobre" no quesito humor. Brincam ou parodiam fazendo referências a personagens bem conhecidos no meio, em apresentações cômicas, que provocam risadas na plateia presente.

Crossplayer: apesar do nome não ser muito bem conhecido no Brasil, alguns "otakus" brasileiros já aderiram à brincadeira. A ideia é trajar-se de personagem do sexo oposto. Desta forma, meninas vestemse como personagens masculinos e meninos vestem-se de acordo com personagens femininas.

Denominamos "costímidos", os cosplayers que não participam das apresentações no palco, nem se candidatam aos concursos, são fiéis à estética das personagens ou dos animês e, em geral, ficam perambulando em meio à multidão. Ao serem questionados, foram ouvidas afirmações de que não gostavam de se apresentar no palco. Apreciavam apenas demonstrar seus cosplays para os presentes e posar para fotos. Essa categoria, em específico, não integra o conjunto de categorias utilizadas pelos "otakus". Foi criada no contexto dessa pesquisa para expressar um comportamento específico de alguns participantes dos eventos.

Cosplay original: categoria criada pelos "otakus". Trata-se da criação de uma personagem por uma pessoa ou design de cosplay também conhecidos como cosmakers, como foi evidenciado em algumas entrevistas concedidas a essa pesquisa:

Tenho um de Full Metal que é os Alquimist do Estado, que eu fiz. [...] Foi uma roupa igual a deles que eu achava legal. (Mileane, 23 anos, MG).

Pesquisador: É como se fosse um dos Alquimistas que não aparece no desenho. Foi você quem criou?

É, eu que criei (risos). Com a [o estilo da] roupa deles. (Mileane, 23 anos, MG).

Um futuro cosplay que eu mesmo pretendo fazer é um ninja, criado por mim mesmo, [...] eu o tenho criado já há um tempo e vou fazer cosplay dele. (Antenor, 19 anos, MG): 
Cosplay hentai: Garotas que geralmente se apresentam com fantasias eróticas, algumas vezes inspiradas em mangás e animês hentais ${ }^{21}$ ou fetiches masculinos. Costumam usar roupas decotadas, ligas, babados, rendas ou trajes sumários.

Cosplay livres: outra categoria nativa, mais identificados com personagens que, além da vestimenta, comportam-se como seus ídolos de diferentes seriados e filmes, inclusive hollywoodianos.

A categoria que provoca mais comentários e interesse entre os frequentadores dos eventos observados foi cosplay oficial ou tradicional (criada pelos organizadores dos eventos).

O objetivo principal dessa categoria é ser o mais fiel possível às personagens dos mangás ou dos animês japoneses, no intuito de competir para vencer campeonatos, elaborando grandes atuações e com efeitos complexos e muito criativos $^{22}$. Alguns dos entrevistados dessa pesquisa referem-se ao tema:

De vez em quando eu uso minha bandana do Naruto, umas coisas diferentes assim. Quando saio para os "animencontros" eu não me preocupo de, por exemplo, se eu estou de cosplay; não me preocupo se vir embora com o cosplay; eu venho com o cosplay mesmo, não ligo. Venho com as touquinhas que a gente usa na cabeça, coisas diferentes assim. (Antenor, 19 anos, MG).

Às vezes eu saio na rua com o braço todo enfaixado; a pessoa acha que eu me machuquei e não sei o que, mas eu estou de cosplay de outro personagem, ai eles acham... eles acham que eu sou louco. (Leandro, 17 anos, DF).

Pesquisador: Mas quando vocês se encontram na rua, vocês se identificam?

Isso, quando eu encontro os "otaku"s eles adoram, tiram foto e tudo o mais. [...] eu posso sair de cosplay, sair na rua vestido de cosplay que eu não me preocupo com o que alguém vai se importar ou o que alguém vai achar. (Marco, 21 anos, DF).

\footnotetext{
${ }^{21}$ De acordo com Rosa (2005), mangás e "animês" hentais são feitos no Japão especificamente para adultos. Segundo Sonia Luyten (2000), o simbolismo sexual está presente nesses produtos porque faz parte da cultura japonesa onde o sexo não é visto como pecaminoso, ao contrário, faz parte dos ritos religiosos e tem um sentido mágico.

${ }^{22} \mathrm{O}$ Brasil já obteve o primeiro lugar por três vezes seguidas em concursos internacionais no Japão e por conta disso já é tri-campeão mundial de cosplay.
} 

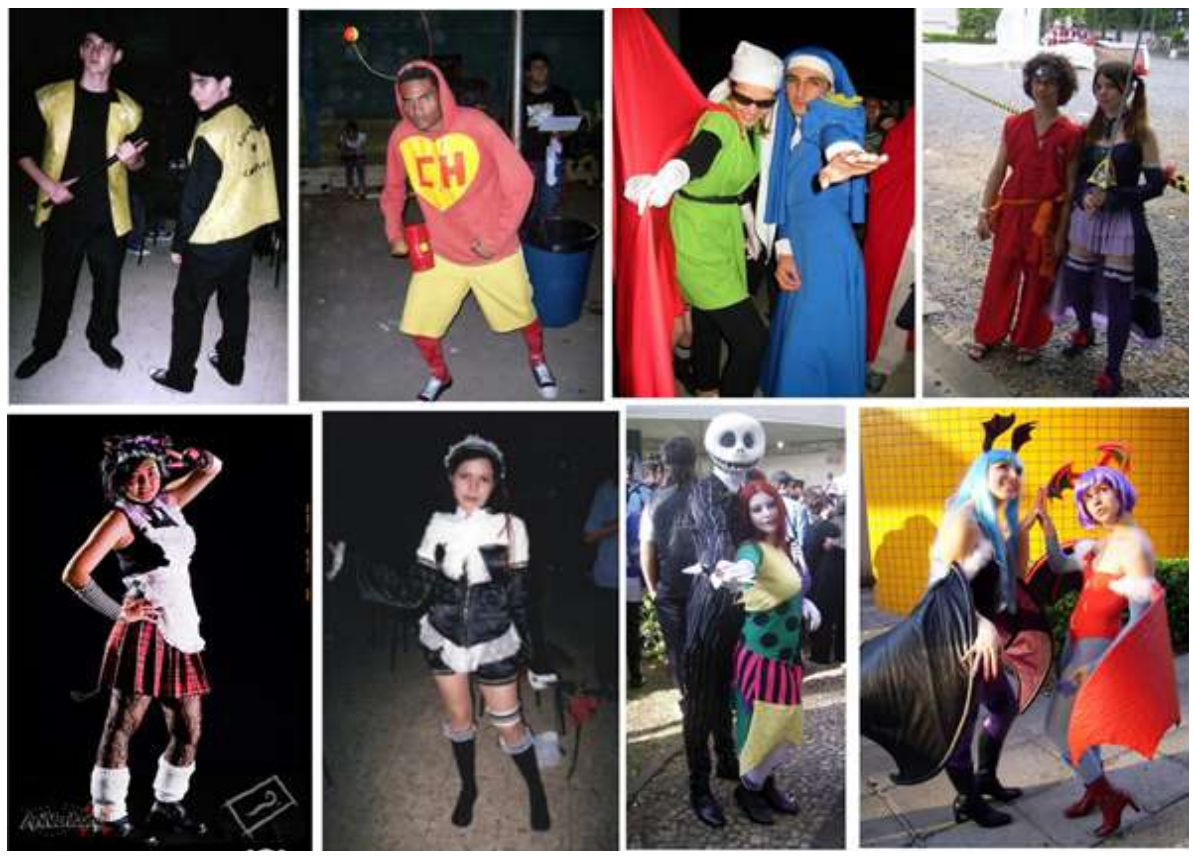

Figura 6 - Da esquerda para a direita: cospobre (RS), toscoplay (CE), crossplayer (SC), costímidos (SC), cosplay original (SC), cosplay hentai (CE), cosplay livre (PR), coplay oficial, ou tradicional (PR).

\section{Considerações finais}

Os resultados desse estudo sugerem que os jovens "otakus", em suas brincadeiras, jogos e diversões, encontram-se e constituem-se como integrantes de uma cultura específica, que produzem e consomem entretenimento. . Como aponta Luyten (2004), o tripé japonês - animê + mangá + videogame - é o principal responsável pela venda e disseminação de produtos derivados destes três gêneros. "Juntos eles formam um círculo gerador de produtos de entretenimento." (p. 20)

Esse trabalho indica a necessidade do conhecimento mais aprofundado desse universo de apropriação da cultura pop japonesa, para que as interpretações de educadores, professores e pais, sobre os comportamentos de jovens relacionados a esse universo não sejam equivocadas, nem preconceituosas. Como nos lembra Neves (2007), mangás, animês e "animencontros" (cultura pop nipônica) são elementos que se movem na mesma velocidade que os jovens, e desta forma desfrutam o que a maioria não percebe. 
Notadamente, esta pesquisa indicou que os jovens “"'otaku”", a partir do que é produzido e veiculado nas mídias (impressa, digital televisiva e radiofônica), criam formas próprias de comunicação, seu próprio dialeto, estilo de danças, seus jogos go e huya. Tudo como resultado híbrido de elementos culturais de origens distintas.

São desenvolvidos saberes específicos que estão sendo aprimorados para o ingresso no mercado, o que acarreta na criação ou no interesse de novas profissões como: desenhistas, designers (cosmakers - confeccionam fantasias profissionalmente), empresários, cantores, dubladores, atores, tradutores, radialistas, roteiristas, editores, organizadores de eventos etc.

É provável que estejamos confirmando os fios das "trilhas invisíveis" do aprender, as quais revelam ser "a educação um amplo processo social que não se resume aos cotidianos institucionais de aprendizagem.” (CARRANO, 2003, p. 19).

Se existe uma relação estreita entre pensamento e linguagem, no sentido de que esta ajuda a configurar aquele, pode-se supor que a linguagem, que se configura nos "animencontros", também é uma animelinguagem, uma construção específica que configura um outro jeito de pensar e de estar no mundo. Os elementos mundializados ajudam a configurar as visões de mundo, percepções etc. É possível supor que o "otaku" veja o mundo de forma diferente por estar mergulhado nessa linguagem diferenciada. "Na essência de sua territorialidade e em seu interior, as culturas são unificadas e sem divisas, distinguindo-se de outras e se determinam por uma "'centralidade' particular". (CANCLINI, 2006). Ou seja, eles compartilham uma forma própria de cultura.

Foi possível também, apreender que os integrantes desse movimento cultural buscam estabelecer coletivamente, formas de garantir um espaço de proximidade entre sua cultura e as culturas subjacentes, aos símbolos e marcas impressos na cultura pop nipônica - com forte cunho mitológico e moral, que se tornaram importante veículo de difusão de valores e pressupostos próprios do Japão - em face do intenso processo de mundialização cultural promovido de maneira especial pelos meios midiáticos. Tudo indica, que esses eventos têm uma função pedagógica no que diz respeito ao conhecimento cada vez mais profundo dessas narrativas, de sua linguagem, seus símbolos, personagens, realizadores e mesmo de suas condições de produção. Estes jovens não buscam ali apenas demonstrar o apreço que sentem pelos desenhos japoneses mas, acima de tudo, ampliar e trocar conhecimentos sobre eles, sobre suas próprias vidas e a cultura que os cerca. 


\section{REFERÊNCIAS}

BARRAL, Étienne. “otaku”: os filhos do virtual. São Paulo: Editora SENAC, 2000.

BRENNER, Ana Karina; DAYRELL, Juarez e CARRANO, Paulo. Juventude brasileira: culturas do lazer e do tempo livre. In: Brasil. Ministério da Saúde. Fundação Oswaldo Cruz. Um olhar sobre o jovem no Brasil. Brasília: Editora do Ministério da Saúde, 2008.

CANCLINE, Nestor García. Culturas Híbridas: estratégias para entrar e sair da modernidade. 4. ed. São Paulo: Universidade de São Paulo, $2006 a$.

. Consumidores e cidadãos. Rio de Janeiro: Editora UFRJ,

6. ed. 2006 b.

CANDAU, Vera. Diferenças culturais, interculturalidade e educação em direitos humanos. Educação \& Sociedade, Campinas, v. 33, n. 118,

p. 235-250, jan.-mar. 2012

CARRANO, Paulo César Rodrigues. Juventudes e cidades educadoras. Petrópolis/RJ: Editora Vozes, 2003.

CASAS, Cecília. Introdução. In: DAVIS, Hadland. Mitos e lendas do Japão. Trad. Cecília Casas, São Paulo: Landy Editora, 2004.

DAYRELL, Juarez. Juventude, grupos culturais e sociabilidade. Jovenes: Revista de Estudios sobre Juventud, ano 9, n²2, janeiro-junho de 2005, Cidade do México, p. 314332.

FREIRE, Marcos. Automassagem e Medicina Chinesa. Brasília: Ed. do autor, 1996.

GRAVET, Paul. Mangá: como o Japão reinventou os quadrinhos. São Paulo: Conrad Editora do Brasil, 2006.

LUYTEN, Sonia Bibe. Mangá: o poder dos quadrinhos japoneses. 2 ed. São Paulo: Hedra, 2000.

. O tripé japonês. In: Bravo! Nov. 2004, ano 5, nº86.

MACIAS, Patrick e EVERS, Izumi. Tokyo Girls. São Paulo: JBC Editora, 2007.

MARTIN-BARBERO, Jésus. Dos meios às mediações: comunicação, cultura e hegemonia. 2. Ed. Rio de Janeiro: Editora UFRJ, 2003.

MOLINÉ, Alfonz. O grande livro dos mangás. 2. ed. Rio de Janeiro: Editora JBC, 2006. 
NAGADO, Alexandre. O mangá no contexto da cultura pop japonesa e universal. In: LUYTEN, Sonia Bibe. (Org.) Cultura Pop Japonesa: mangá e animê. São Paulo: Hedra, 2005.

NEVES, Leonardo Azevedo. mangás e marcas identitárias juvenis: um novo olhar para a relação entre mídia e a educação. Diss. (Mestrado) Universidade Estadual do Rio de Janeiro - UERJ, 2007.

ORTIZ, Renato. A moderna tradição brasileira: cultura brasileira e indústria cultural. São Paulo: Brasiliense, 1994.

. Entrevista Desafios da globalização, 2002, organização de Landislau Dowbor, Octavio Ianni e Paulo Edgar A Resende, da Editora Vozes. Educação, Empresa Municipal de Multimeios - MultiRio, Século XX1, Rio de Janeiro: Extraído de http:// www.multirio.rj.gov.br/sec21/chave_artigo.asp?cod_artigo=37 em 07 de março de 2008 .

. Mundialização e cultura. São Paulo: Brasiliense, 2003.

ROSA POITRAS, Guilles. The Anime Companion: what's japanese in japanese animation?. Berkeley, Califórnia: Stone Bridge Press, 2005.

SATO, Cristiane Akune. Japop: o poder da cultura pop japonesa. São Paulo: NSP Hakkosha, 2007.

SMIRKOFF, Marcos. Anime: a animação no Japão. In: Coletânea lições com cinema: animação. São Paulo: FDE, Diretoria de Projetos Especiais/Diretoria Técnica, 1996. v.4.

VASCONCELLOS, Pedro Vicente Figueiredo. Mangá-dô: os caminhos das histórias em quadrinhos japonesas. Diss. (Mestrado) Rio de Janeiro: Departamento de Artes e Design, Pontifícia Universidade Católica do Rio de Janeiro (PUC-Rio), 2016. 